\title{
MARGUERITE DURAS E A AUTOFICÇÃO CONSTRUÍDA PELA REESCRITURA
}

\author{
MARGUERITE DURAS AND THE AUTOFICTION BUILT BY \\ REWRITING
}

\begin{abstract}
Andréa Correa Paraiso MÜLLER ${ }^{1}$
Resumo: Ao longo das últimas décadas, diversos estudos acadêmicos dedicaram-se a refletir sobre os aspectos autobiográficos da obra de Marguerite Duras, particularmente de $O$ amante que, desde a sua publicação, em 1984, tem recebido diferentes rótulos, como autobiografia, romance autobiográfico e autoficção. Entendemos que os possíveis aspectos autobiográficos do romance não podem ser analisados isoladamente. No percurso de escrita de Marguerite Duras, os textos remetem uns aos outros, em um processo singular de intertextualidade do qual emerge a figura de um eu comum ao conjunto desses textos. Pensar, portanto, em escrita de si ou em autoficção na obra de Duras faz sentido quando se considera o processo de reescritura, tão característico da produção da autora. No presente artigo, a partir do suporte de teóricos da autobiografia e da autoficção, temos por objetivo analisar a construção desse sujeito que diz eu no universo ficcional durassiano, construído pela reescritura que permite interpretar como autoficção a relação entre os textos e não um texto isolado.
\end{abstract}

Palavras-chave: Marguerite Duras. Autoficção. Reescritura. Literatura. Século XX.

\begin{abstract}
Over the last few decades, several academic studies have been devoted to the reflection upon autobiographical aspects of Marguerite Duras' works, particularly The Lover, which since its publication in 1984 has received different labels, such as autobiography, autobiographical novel and autofiction. We understand that the possible autobiographical aspects of this novel cannot be analysed in isolation. Throughout Marguerite Duras' writing production, her texts make reference to one another, in a singular process of intertextuality from which emerges the figure of a common "self" to all these texts. To think, therefore, in self-writing or autofiction in her work makes sense when the rewriting process is taken into consideration, for being a characteristic feature in Duras' production. With the help of autobiography and autofiction theoreticians framework, this paper aims at analysing the construction of the subject who claims the 'self' in Duras' fictional universe, built by her rewriting which allows the interpretation of the relation between the texts, rather than an isolated text as autofiction.
\end{abstract}

Keywords: Marguerite Duras. Autofiction. Rewriting. Literature. XX Century.

\section{Introdução}

Na fortuna crítica de Marguerite Duras, não são raros os estudos que se debruçam sobre a escrita de si. Diversos trabalhos dedicam-se a apontar, particularmente em $O$ amante ( $L$ 'amant), traços da autobiografia, do romance autobiográfico e da autoficção.

\footnotetext{
${ }^{1}$ Doutora em Teoria e História Literária pela Universidade Estadual de Campinas (UNICAMP). Professora adjunta de Literatura Francesa do Departamento de Estudos da Linguagem da Universidade Estadual de Ponta Grossa/PR (UEPG) e docente permanente do Programa de Pós-graduação em Estudos da Linguagem da UEPG. andreaparaisomuller@gmail.com
} 
Publicado em 1984, após mais de trinta anos do início da carreira literária de Duras, $O$ amante é o primeiro texto da autora escrito na primeira pessoa. Foi recebido por boa parte do público e da crítica, à época, como autobiografia, rótulo esse amplamente questionado e discutido por trabalhos posteriores. Entendemos que os possíveis aspectos autobiográficos do texto não podem ser analisados isoladamente. É a reescritura que permite a construção do sujeito que diz eu na produção de Duras.

O que buscamos neste artigo não é identificar os elementos autobiográficos na obra de Marguerite Duras ou verificar se o narrado corresponde ao vivido. Interessa-nos observar de que maneira se constrói na produção da autora, por meio de recursos próprios da narrativa literária, a figura de um eu-escritora que produz um efeito autobiográfico, efeito esse que, a partir de $O$ amante, estende-se a textos anteriores.

\section{A obra de Marguerite Duras: uma trajetória de reescritura}

Quando publicou $O$ amante, em 1984, Marguerite Duras já era um nome importante na intelectualidade francesa e já produzira uma obra vasta e diversificada, que passeia entre a literatura, o cinema e o teatro.

Sua estreia literária se dá em 1943 com o romance Les impudents ${ }^{23}$, que não teve boa recepção crítica e chegou a ser renegado pela própria autora. Os primeiros livros seguem ainda a linha do romance tradicional, com enredos lineares. Já deixam transparecer, contudo, muitos dos temas que se tornariam característicos do universo durassiano: o amor e o ódio dentro da família, a loucura, a obsessão e a morte.

O primeiro romance de grande sucesso é Un barrage contre le Pacifique (Barragem contra o Pacífico), de 1950. Ainda conservando as características realistas de Les Impudents e La vie tranquille 4 (1944), Barragem contra o Pacífico coloca em cena, pela primeira vez, personagens e episódios que seriam retomados e recriados em $O$ amante e em $O$ amante da China do Norte (1991). A narrativa, conduzida em terceira pessoa, tem como cenário a Indochina da infância e adolescência da escritora. A figura da mãe é central no romance, que apresenta, pela primeira vez, a história da concessão de terras e das barragens erguidas contra o Pacífico: uma professora primária francesa vivendo na Indochina com seus filhos, Suzanne e

\footnotetext{
${ }^{2}$ Neste artigo, as obras que não foram traduzidas para o português terão seus títulos grafados apenas no idioma original.

${ }^{3}$ DURAS, Marguerite. Les impudents. Paris: Plon, 1943.

${ }^{4}$ DURAS, Marguerite. La vie tranquille. Paris: Gallimard, 1944.
} 
Joseph, investe todas as suas economias em uma concessão de terras que obtém da administração colonial. Quando as terras se revelam incultiváveis (invadidas pelas águas do oceano nos períodos de maré alta), ela constrói barragens, na tentativa de salvar suas colheitas futuras. Tais barragens, no entanto, construídas sem conhecimento técnico, sucumbem à força das águas.

É também em Barragem contra o Pacífico que surge a figura do chinês, reformulada mais tarde no personagem de $O$ amante. M. Jo é o homem rico e, em certa medida, repulsivo, que expressa seu desejo por Suzanne.

Ainda em Barragem contra o Pacífico, é narrada pela primeira vez a história da mendiga indiana. Expulsa de casa com seu bebê, ela caminha rumo a Calcutá. Ao passar pelo Mekong, sem condições de manter a criança, encontra como solução doá-la a uma mulher branca (a mãe, personagem central do romance). Doente, a criança morre pouco tempo depois. Esse episódio viria a ser retomado em livros ulteriores da escritora. A mendiga torna-se signo de loucura e errância.

A partir de Moderato Cantabile 5 (1958), a escrita de Duras começa a apresentar os traços que viriam a lhe ser característicos: metalinguagem, repetição voluntária e ruptura da ilusão referencial.

Em 1959, Duras escreve o roteiro de Hiroshima mon amour ${ }^{6}$, filme de Alain Resnais (o roteiro seria publicado pela Gallimard no ano seguinte). Experimenta, pois, a linguagem do cinema, que viria a ser mais explorada anos mais tarde, quando a escritora dirige seus próprios filmes.

Com Le ravissement de Lol V. Stein ${ }^{7}$, de 1964, as reviravoltas da memória assumem papel importante nos textos de Duras. A narrativa torna-se fragmentada, deixando ao leitor a incumbência de reconstituir a história.

Em Le vice-consul ${ }^{8}$, publicado no ano seguinte, a mendiga indiana retorna, dessa vez como tema central. A personagem voltaria a aparecer em Amor (1975), India song (1973) e $O$ amante.

A partir de Détruire, dit-elle ${ }^{9}$, de 1969, os textos de Duras vão se tornando cada vez mais rarefeitos, distanciando-se progressivamente da narrativa tradicional.

\footnotetext{
${ }^{5}$ DURAS, Marguerite. Moderato cantabile. Paris: Éditions de minuit, 1958.

${ }^{6}$ DURAS, Marguerite. Hiroshima mon amour. Scénarios et dialogues. Paris: Gallimard, 1960.

${ }^{7}$ DURAS, Marguerite. Le ravissement de Lol V. Stein. Paris: Gallimard, 1964.

${ }^{8}$ DURAS, Marguerite. Le vice-consul. Paris: Gallimard, 1965.

${ }^{9}$ DURAS, Marguerite. Détruire, dit-elle. Paris: Éditions de minuit, 1967.
} 
Ao longo da década de 1970, a autora dedica-se ao cinema: escreve roteiros, adapta textos seus e dirige seus próprios filmes. Assim como seus textos literários, seu cinema também é de ruptura com o convencional. Duras sempre recusou os filmes feitos para o consolo e a evasão: "Ela espera que seu espectador seja adulto, isto é, que não se esqueça de si, que não deixe o filme apoderar-se dele" (AYER, 2014, p. 8, grifo do autor).

Além do cinema e da literatura, Duras também escreveu diversas peças teatrais. L'Éden cinéma, de 1977, retoma a história narrada em Barragem contra o Pacífico. O enfoque recai, entretanto, sobre a construção da ficção. A peça é fortemente metateatral e questiona os limites entre o teatro e a narrativa literária.

A publicação de $O$ amante, em 1984, inaugura, segundo Leyla Perrone-Moisés (1996), a "fase transparente" da produção durassiana, com narrativas que deixam de lado o hermetismo de fases anteriores, mas mantêm a metalinguagem, a ambiguidade e a profunda reflexão sobre a construção da narrativa.

Em 1991, após a polêmica que opôs Marguerite Duras ao cineasta Jean-Jacques Annaud em relação ao filme $O$ amante (Duras não teria gostado da adaptação de seu romance feita por Annaud), a escritora publica L'amant de la Chine du Nord (O amante da China do Norte). A história narrada em $O$ amante é recriada. Inserindo-se em um ciclo de reescritura que une três obras (Barragem contra o Pacífico, L'Éden cinéma e O amante), L'amant de la Chine du Nord é apresentado pela autora como romance, mas aproxima-se de um roteiro cinematográfico. Podendo ser interpretado como possibilidade de realização fílmica de $O$ amante, trata-se de um texto híbrido, que propicia uma profícua reflexão sobre as possibilidades narrativas no cinema e na literatura.

A partir de 1992, Duras dedica-se a textos mais curtos, que abordam o cotidiano da escrita. Écrire (Escrever), de 1993, evoca momentos, pessoas e textos e centra-se na rememoração da escrita.

Em setembro de 1995, seis meses antes de morrer, a escritora publica seu último livro, que recebe o sugestivo título de C'est tout. Concebido sob a forma de diálogo entre Duras e seu companheiro Yann Andréa, o texto faz uma espécie de balanço da vida e da obra, promovendo quase uma fusão entre as duas.

\section{Autoficção construída pela reescritura a partir de $O$ amante}


A publicação de $O$ amante quando Marguerite Duras já havia atingido amplo reconhecimento e repercussão em sua carreira literária despertou a curiosidade de público e crítica. O texto de tom retrospectivo, conduzido em primeira pessoa, foi logo recebido como autobiografia da escritora. Até mesmo o cartaz de divulgação veiculado à época, mostrando uma fotografia de Duras diante do espelho, contribuiu para reforçar essa interpretação.

Não demoraram a surgir estudos questionando essa primeira classificação e buscando enquadrar o texto em outras categorias de escritas do eu, como o romance autobiográfico e a autoficção.

À primeira vista, $O$ amante parece corresponder à definição de autobiografia formulada por Philippe Lejeune no clássico ensaio "Le pacte autobiographique": "narrativa retrospectiva em prosa que uma pessoa real faz de sua própria existência enfocando sua vida individual, particularmente a história de sua personalidade" (LEJEUNE, 1975, p. 14, tradução nossa) ${ }^{10}$. A narradora parte da imagem do seu rosto "devastado" pelos anos para narrar sua história pessoal, explicar como se deu o envelhecimento:

\footnotetext{
Um dia, eu já tinha bastante idade, no saguão de um lugar público, um homem se aproximou de mim. Apresentou-se e disse: "Eu a conheço desde sempre. Todo mundo diz que você era bonita quando jovem; venho lhe dizer que, por mim, eu a acho agora ainda mais bonita do que quando jovem; gostava menos do seu rosto de moça do que do rosto que você tem agora, devastado".

Penso com frequência nessa imagem que sou a única ainda a ver e que nunca mencionei a ninguém. [...]

Muito cedo foi tarde demais em minha vida. Aos dezoito anos já era tarde demais. Entre os dezoito e os vinte e cinco anos, meu rosto tomou um rumo imprevisto. Aos dezoito envelheci (DURAS, 2012, p. 7).
}

O rosto é o gatilho para a memória. A imagem, que permanece como uma fotografia jamais tirada, engendra a reflexão sobre si, que vai levar ao retrospecto, à busca do passado individual:

\begin{abstract}
Penso com frequência nessa imagem que sou a única ainda a ver e que nunca mencionei a ninguém. Ela continua lá, no mesmo silêncio, fascinante. Entre todas as imagens de mim mesma, é a que me agrada, nela me reconheço, com ela me encanto. [...] Aos dezoito anos envelheci. [...] Esse envelhecimento foi brutal. Eu o vi ganhar meus traços, um a um, mudar a relação que existia entre eles, aumentar os olhos, entristecer o olhar, marcar mais a boca, imprimir profundas gretas na testa. [...] Tenho um rosto lacerado por rugas secas e profundas, a pele sulcada. Ele não decaiu como certos rostos de traços finos; manteve os mesmos contornos, mas sua matéria se destruiu. Tenho um rosto destruído (DURAS, 2012, p. 7-8).
\end{abstract}

\footnotetext{
${ }^{10}$ No original: "récit rétrospectif en prose qu'une personne réelle fait de sa propre existence, lorsqu'elle met l'accent sur sa vie individuelle, en particulier sur l'histoire de sa personnalité" (LEJEUNE, 1975, p. 14).
} 
A imagem do rosto devastado desencadeia, pois, a narrativa, desperta o desejo de revisitar o passado pela escrita. Imediatamente após a reflexão sobre as marcas do tempo em sua face, a narradora evoca a época em que tinha quinze anos e meio e em que ainda não era "tarde demais" em sua vida:

Permitam-me dizer, tenho quinze anos e meio.

Uma balsa desliza sobre o Mekong.

A imagem permanece durante toda a travessia do rio.

Tenho quinze anos e meio, esse país não tem estações, vivemos numa estação só, quente, monótona; vivemos na longa zona quente da terra, sem primavera, sem renovação (DURAS, 2012, p. 8).

Como observa Aliette Armel (1996, p. 6), O amante apresenta-se como uma busca das origens, uma tentativa de recuperar a época em que o rosto ainda estava intacto. E, ao encontrar esse passado longínquo, a narrativa presentifica-o. Quando são narrados episódios de quando a narradora tinha quinze anos e meio, o tempo verbal utilizado é o presente do indicativo, como se os acontecimentos se desenrolassem no instante da narração:

É, portanto, durante a travessia de balsa de um braço do Mekong entre Vinhlong e Sadec, na grande planície de lodo e arroz do sul da Cochinchina, a planície dos Pássaros.

Desço do ônibus. Vou até a amurada. Olho o rio. [...] Estou com um vestido de seda natural, gasto, quase transparente (DURAS, 2012, p. 13).

O envolvimento com o amante chinês, os problemas familiares e todos os fatos situados no período em que a narradora tinha quinze anos e meio são acontecimentos passados, recordados na narrativa. Entretanto, são narrados no presente do indicativo, diferentemente de passagens em que são relatados fatos mais recentes. $O$ efeito que se produz é o de presentificação do vivido: a narradora não apenas recorda sua adolescência, mas a revive, tornaa presente por meio da narrativa. Se, como entende Aliette Armel, $O$ amante se apresenta como uma busca das origens, narrar acontecimentos passados utilizando o presente do indicativo corresponde a cumprir plenamente essa busca. O passado, além de rememorado, é presentificado, revivido.

O fio condutor dessa narrativa retrospectiva é a memória. São relatados fatos ocorridos em diferentes momentos da vida da narradora, mas a ordem em que são dispostos no texto não é, de forma alguma, a cronológica. A narrativa salta de um passado recente para um passado longínquo, volta novamente para um tempo próximo do da narração, de novo vai para um 
passado distante... O discurso organiza-se, pois, pelas recordações, que vêm à mente livres de linearidade temporal.

Além de conduzir o ritmo, a memória é um dos elementos-chave na construção da narrativa. É ela que permite a presentificação do passado. O texto todo é pontuado por expressões que remetem ao ato de recordar. O verbo lembrar-se (se souvenir, no original) é diversas vezes empregado, assim como esquecer-se (oublier):

E naquela manhã peguei o ônibus em Sadec, onde minha mãe é diretora da escola feminina. É o fim das férias escolares, não lembro bem quais (DURAS, 2012, p. 12).

A ambiguidade determinante da imagem está nesse chapéu.

Como ele chegou até mim, esqueci. Não imagino quem poderia ter me dado. Acho que foi minha mãe que comprou, a pedido meu. Única certeza, era um saldo de liquidação (DURAS, 2012, p. 14).

O ruído da cidade é muito forte, na minha memória é o som de um filme alto demais, ensurdecedor. Lembro bem, o quarto está escuro [...] (DURAS, 2012, p. 37).

Ainda revejo o rosto, e lembro o nome (DURAS, 2012, p. 40).

Marie-Claude Carpenter. Ela era americana, de Boston, se bem me lembro (DURAS, 2012, p. 56).

Não me lembro bem dos dias. A claridade solar embaçava as cores, esmagando-as. Das noites eu me lembro (DURAS, 2012, p. 70).

A presença constante da memória, organizando a narrativa e conferindo ao discurso um caráter de evocação, contribui para produzir um efeito autobiográfico. Dizer "eu me lembro" é, de certa forma, afirmar que se está narrando fatos vivenciados. É também, ao mesmo tempo, chamar a atenção para o processo de escrita, como se pode observar no trecho a seguir: "No momento em que escrevo, lembro que nosso irmão mais velho não estava em Vinhlong quando se lavava a casa com toda aquela água" (DURAS, 2012, p. 54). Essa passagem provoca certa ilusão de realidade, produzindo um efeito de confissão, de autobiografia. Ao mesmo tempo, revela a metalinguagem ("No momento em que escrevo"), desnuda o processo de construção do texto. A narradora se mostra escrevendo e ressalta que sua matéria-prima é a memória.

É possível afirmar, então, que todos esses procedimentos apontados até agora produzem efeito autobiográfico. Entretanto, não são suficientes para que se possa considerar $O$ amante como uma autobiografia propriamente dita. O efeito autobiográfico convive e relaciona-se com efeitos de ficção. Na abertura do texto, como já apontamos, há um tom de narrativa confessional, de história de vida. Algumas páginas depois, esse tom é rompido, e a suposta 
autobiografia é questionada: “A história da minha vida não existe. Ela não existe. Nunca há um centro" (DURAS, 2012, p. 10).

Não existe a história da vida, e sim a escrita da vida. O tempo vivido é recriado pela imaginação. Como afirmou a própria Duras em entrevista concedida na época do lançamento de $O$ amante, a história da vida não existe, apenas o romance da vida:

A história da sua vida, da minha vida, elas não existem, ou então se trata de lexicologia. O romance da minha vida, das nossas vidas, sim, mas não a história. É na retomada dos tempos pelo imaginário que o sopro é devolvido à vida (DURAS apud ARMEL, 1996, p. 131, tradução nossa). ${ }^{11}$

Duras não assume plenamente a autobiografia, nem na voz das instâncias criadas no texto literário, nem em suas declarações ditas extratextuais, como, por exemplo, nas entrevistas. $\mathrm{O}$ efeito autobiográfico é afirmado e rompido diversas vezes, evidenciado e questionado ao mesmo tempo, fundamentado em sua própria ambiguidade constitutiva.

É importante ressaltar que esse efeito autobiográfico que se observa em $O$ amante não corresponde a um "pacto autobiográfico" tal qual o concebe Lejeune. Para o teórico, o nome próprio tem papel fundamental na autobiografia. O "pacto autobiográfico" residiria na afirmação, no texto, da identidade entre autor, narrador e personagem principal, remetendo ao nome próprio na capa do livro (LEJEUNE, 1975, p. 22). Ora, a narradora de $O$ amante não é nomeada, o que impossibilita essa identificação concreta. Os indícios que remetem à autobiografia são formulados e rompidos o tempo todo, produzindo ambiguidade e questionando a própria autobiografia como gênero. Como bem observa Monique Pinthon (2009, p. 38), o texto de Duras “perturba os códigos da autobiografia”, introduzindo a dúvida no lugar do pacto de realidade:

Marguerite Duras não cessa de pôr em dúvida a verdade ingênua da autobiografa e
afirma, ao contrário, o caráter indeterminável de uma vida que se deixa entrever
melhor nos meandros da transposição ficcional do que no domínio de uma narrativa
organizada que se pretende fiel (PINTHON, 2009 , p. 40 , tradução nossa). ${ }^{12}$

${ }^{11}$ No original: 'L'histoire de votre vie, de ma vie, elles n'existent pas, ou bien alors il s'agit de lexicologie. Le roman de ma vie, de nos vies, oui, mais pas l'histoire. C'est dans la reprise des temps par l'imaginaire que le souffle est rendu à la vie" (DURAS apud ARMEL, 1996, p. 131).

12 No original: "Marguerite Duras ne cesse de mettre en doute la vérité naïve de l'autobiographie et affirme au contraire le caractère indécidable de la vérité d'une vie qui se laisse mieux entrevoir dans les méandres de la transposition fictionnelle que dans la maîtrise d'un récit ordonné et qui se veut fidèle" (PINTHON, 2009, p. 40). 
Diante, pois, da impossibilidade de classificar $O$ amante como autobiografia e, ao mesmo tempo, em face das inegáveis marcas de uma escrita do eu, diversos estudos consideram mais adequado situar o texto de Duras no terreno impreciso da autoficção.

Definido e posto em prática pelo francês Serge Doubrovsky em seu romance Fils, de 1977, o termo autoficção designaria uma obra romanesca - portanto, com tratamento ficcional da matéria - na qual coincidiriam os nomes de autor, narrador e personagem principal. Para o escritor e professor, depois da psicanálise e dos estudos que se desenvolveram sobre o sujeito ao longo do século XX, tornou-se ilusório acreditar que se pode dar conta da complexidade de uma existência por meio de uma narrativa linear, cronologicamente organizada:

\footnotetext{
A atitude clássica do sujeito que tem acesso, através de uma introspecção sincera e rigorosa, às profundezas de si passou a ser uma ilusão. O mesmo acontece com relação à restituição de si através de uma narrativa linear, cronológica, que desnude enfim a lógica interna de uma vida (DOUBROVSKY, 2014, p. 123).
}

A autoficção implicaria, para Doubrovsky, a reinvenção, a recriação. As experiências do eu seriam retrabalhadas, recriadas na escrita. O material abordado não seria apresentado como reprodução, mas como reinvenção. Neste sentido, os procedimentos observados em $O$ amante aproximam-se bastante desse conceito: a narrativa fragmentada, guiada pelo fluir da memória, que traz à tona diferentes momentos de um mesmo passado, sem perseguir uma ilusão de completude ou uma artificial linearidade parece encontrar eco no que afirma Doubrovsky:

\footnotetext{
Não percebo de modo algum minha vida como um todo, mas como fragmentos esparsos, níveis de existência partidos, frases soltas, não coincidências sucessivas, ou até simultâneas. É isso que preciso escrever. O gosto íntimo da existência, e não sua impossível história (DOUBROVSKY, 2014, p. 123).
}

O próprio Doubrovsky (2014, p. 120) admite a imprecisão do termo por ele formulado e os múltiplos usos e leituras que a palavra recebeu ao longo dos anos. Há quem acredite que todo texto autobiográfico é, de certa forma, autoficção. No entanto, há certos elementos que caracterizam e definem o gênero. Anna Faedrich (2015, p. 49) aponta a ambiguidade como algo fundamental na autoficção:

Já na autoficção se estabelece com o leitor um pacto oximórico (JACCOMARD, 1993), que se caracteriza por ser contraditório, pois rompe com o princípio de veracidade (pacto autobiográfico), sem aderir integralmente ao princípio de invenção (pacto romanesco/ficcional). Mesclam-se os dois, resultando no contrato de leitura, marcado pela ambiguidade, em uma narrativa intersticial (FAEDRICH, 2015, p. 46, grifo da autora). 
Estabelece-se, pois, na autoficção, um pacto ambíguo, contraditório: ao mesmo tempo em que há coincidência de nomes entre autor, narrador e protagonista, os limites entre real e ficcional são intencionalmente transpostos, num propósito de "confundir o leitor e provocar uma recepção contraditória da obra" (FAEDRICH, 2015, p. 49). A autoficção quebra as expectativas do leitor, levando-o a refletir e a questionar as definições genéricas e as formas tradicionais. Muitos textos, mesmo trazendo na capa a menção "romance", aproximam-se da autobiografia, implodindo as fronteiras rígidas entre autobiográfico e ficcional e obrigando o leitor a assumir uma atitude de "suspeitar" das estratégias narrativas à medida que reflete sobre elas. A autoficção teria, pois, um componente metalinguístico. Philippe Gasparini (2014, p. 195) chama a atenção para o "trabalho textual" como critério de autoficcionalidade, expresso por uma "busca de uma forma original; uma reconfiguração não linear do tempo".

A escrita de Duras assenta-se sobre esse pacto ambíguo. A identificação entre autora, narradora e personagem não pode ser atestada por nomes próprios, mas indícios como, por exemplo, a menção ao rosto, apontam para essa consonância. Lembremos também que, como observa Faedrich (2015, p. 50), essa identidade onomástica que ocorre na autoficção pode, por vezes, aparecer disfarçada. No entanto, a afirmação da ficção vem romper a expectativa de uma autobiografia propriamente dita: "a história da minha vida não existe". $O$ amante mergulha o leitor em um constante ir e vir entre o tom fortemente confessional e a impossibilidade de realização dessa escrita autobiográfica. E essa ambiguidade constitutiva do romance de Duras favorece a reflexão sobre a própria construção da narrativa.

Um dos exemplos mais significativos desse pacto contraditório é a irrupção do pronome "ela" que, em diversas passagens, ocupa o lugar do "eu". O eu que conduz o relato subjetivo, confessional, por vezes esconde-se por trás do pronome de terceira pessoa. E, assim, episódios bastante significativos dessa narrativa do passado, pertencentes de modo específico ao período da adolescência da narradora/personagem, são relatados como se, aparentemente, essas duas instâncias fossem separadas. A narradora que vinha empregando a primeira pessoa passa a designar-se como "ela", “a menina", "a jovem", “a criança":

\footnotetext{
A menina com chapéu de feltro está na luz barrenta do rio, sozinha no convés da balsa, apoiada na amurada. O chapéu masculino tinge toda a cena de róseo. [...] A menina conhece o barqueiro desde criança. O barqueiro lhe sorri e pede notícias da senhora diretora. [...] A mãe vai bem, diz a menina (DURAS, 2012, p. 21-22).

O homem elegante desceu da limusine, ele fuma um cigarro inglês. Olha a jovem com chapéu masculino e sapatos dourados. Aproxima-se devagar. Visivelmente intimidado. De início não sorri. De início oferece um cigarro a ela. A mão treme. [...] Ela lhe diz que não fuma, não, obrigada (DURAS, 2012, p. 30).
} 
Na narração desse primeiro encontro com o chinês que se tornaria amante, o emprego da terceira pessoa faz supor uma dissociação entre narradora e personagem. Se observarmos o texto original em francês, no entanto, será possível concluir que a narradora continua presente, situada ao lado da personagem, ou melhor, situada na personagem, enxergando os acontecimentos do ponto de vista da jovem de chapéu masculino e sapatos dourados. O trecho traduzido como "Aproxima-se devagar" é, originalmente, "Il vient vers elle lentement" (DURAS, 1984, p. 42). O verbo venir (vir) coloca narradora e personagem juntas na mesma perspectiva. Escondida atrás do pronome ela ainda está a mesma narradora que diz eu. Nas passagens do texto em que o passado mais distante parece ser revivido, em que a narradora de rosto devastado reencontra e recria a menina de quinze anos e meio, o eu desmembra-se em eu/ela. O pacto novamente é problematizado, posto em dúvida. O leitor é convidado a refletir, a interrogar-se sobre esse eu autobiográfico que assume a máscara do ficcional. O emprego da terceira pessoa evidencia a distinção entre o eu que narra e o ela narrado, ao mesmo tempo em que ambas continuam sendo a mesma. Tal procedimento entrelaça os dois efeitos que se produzem no texto (de autobiografia e de ficção) e a partir dos quais se funda a ambiguidade de $O$ amante. E essa ambiguidade convida a refletir sobre a própria escrita, a entender esses dois efeitos como possibilidades de uma narrativa que se volta constantemente para o seu próprio processo de elaboração.

Dessa forma, tendemos a concordar com os pesquisadores que afirmam que $O$ amante não pode ser interpretado como autobiografia propriamente dita, mas como autoficção. Entretanto, em Marguerite Duras a reescritura é uma particularidade fundamental para a constituição do sentido da obra como conjunto. Personagens e episódios são retomados, modificados, recriados. Um texto remete ao outro, corrigindo-o e reescrevendo-o; um novo texto modifica a leitura de textos precedentes. Considerando esse processo, torna-se complicado analisar isoladamente certos textos de Duras. Assim, associar $O$ amante à autoficção implica integrar a essa interpretação outros textos da produção durassiana retomados pelo romance de 1984. O pacto ambíguo de $O$ amante atingiria, pela reescritura, textos anteriores, particularmente Barragem contra o Pacífico, cujo contrato de leitura seria diferente em uma análise isolada. E textos posteriores a $O$ amante, mas que o retomam, também comporiam esse conjunto de reescritura autobiográfica ambígua. 
As referências aos textos anteriores se relacionam à constituição de um sujeito-escritora que se identifica com a narradora de $O$ amante e assume como seus os textos aos quais se refere. Logo nas primeiras páginas do romance, a reescritura é explicitada:

\begin{abstract}
Escrevi muito sobre essas pessoas da minha família, mas enquanto ainda estavam vivas, a mãe e os irmãos, e escrevi sobre eles, sobre essas coisas sem chegar diretamente até elas. [...] A história de uma minúscula parte de minha juventude, já a escrevi mais ou menos, enfim, quero dizer, dei-a a perceber; falo justamente desta parte, a da travessia do rio. O que faço aqui é diferente, e parecido. Antes, falei dos períodos claros, dos que estavam esclarecidos. Aqui falo dos períodos encobertos dessa mesma juventude, de certos fatos, certos sentimentos, certos acontecimentos que enterrei (DURAS, 2012, p. 10-11).
\end{abstract}

A passagem acima transcrita explicita e ressalta a reescritura, ao mesmo tempo em que contribui para produzir efeito autobiográfico. À medida que a narradora assume situações narradas em outros livros, reforça-se a identificação entre personagem, narradora e autora:

\begin{abstract}
Nas histórias de meus livros que remetem à minha infância, de repente não sei mais o que evitei dizer, o que disse, acho que falei do amor que sentíamos por nossa mãe, mas não sei se falei do ódio que também sentíamos por ela e o amor que sentíamos uns pelos outros, e o ódio também, terrível, nessa história comum de ruína e morte que era a dessa família em qualquer caso, de amor ou de ódio, e que ainda não consigo entender plenamente, ainda me é inacessível, oculta no mais fundo de minha carne, cega como um recém-nascido no primeiro dia de vida (DURAS, 2012, p. 25).
\end{abstract}

Instala-se um eu supostamente autobiográfico (já discorremos aqui sobre a ambiguidade desse eu que mescla autobiográfico e ficcional), que é também um eu-escritora. Esse eu se constrói como sujeito da narrativa confessional de $O$ amante e de todas as narrativas nela retomadas. Em lugar de simplesmente um sujeito do vivido, compõe-se como um sujeito da escrita, um eu que se mostra escrevendo e que narra sua história como personagem que quer escrever:

Quero escrever. Já disse para minha mãe: o que eu quero é isso, escrever. Nenhuma resposta na primeira vez. E depois ela pergunta: escrever o quê? Digo livros, romances (DURAS, 2012, p. 21).

Respondi que o que mais queria, acima de qualquer outra coisa, era escrever, só isso, nada mais (DURAS, 2012, p. 22).

Está acabado, não me lembro mais. É por isso que escrevo sobre ela, agora, de modo tão fácil, tão longo, tão estirado, ela se tornou escrita corrente (DURAS, 2012, p. 27).

Nas referências a essas "histórias de meus livros que remetem à minha infância", o leitor vai identificando os textos de Duras anteriores a $O$ amante, mais especificamente Barragem 
contra o Pacífico: "Quando estou na balsa do Mekong, esse dia da limusine preta, minha mãe ainda não abandonou a concessão da barragem" (DURAS, 2012, p. 25). Ora, a história da concessão e das barragens é narrada em Barragem contra o Pacífico e retomada na peça de teatro L'Éden cinéma. No entanto, a narradora de $O$ amante refere-se a ela como algo já conhecido do leitor; dirige-se, pois, a um leitor também dos outros textos, um leitor da reescritura.

É a esse leitor de Barragem contra o Pacífico que a narradora/escritora se dirige quando retoma episódios e faz correções: "Portanto, vejam, não é na cantina de Réam, como eu havia escrito, que encontro o homem rico da limusine preta, é depois do abandono da concessão, dois ou três anos depois, na balsa, nesse dia que estou relatando, nessa luz de bruma e de calor" (DURAS, 2012, p. 26). Em Barragem contra o Pacífico, assim como em sua versão teatral, é justamente na cantina de Réam que a personagem Suzanne conhece o rico chinês M. Jo. Esse leitor é, por vezes, interpelado, chamado ao diálogo. A narradora/escritora imagina suas questões e as responde, criando um jogo que desnuda a reescritura:

Na balsa, ao lado do ônibus, há uma grande limusine preta com um motorista de libré de algodão branco. Sim, é o grande carro fúnebre dos meus livros. É o Morris LéonBollée. O Lancia preto da embaixada da França em Calcutá ainda não fez seu ingresso na literatura (DURAS, 2012, p. 18).

O trecho citado faz referência a Barragem contra o Pacífico, em que aparece o Morris Léon-Bollée, e a Le ravissement de Lol V. Stein e Le vice-consul, em que surge o carro preto do embaixador da França. Em Barragem contra o Pacífico e em L'Éden cinéma, o Morris LéonBollée é o carro de M. Jo, o chinês rico que se interessa por Suzanne:

- Qual é a marca? - perguntou Suzanne.

- É um Maurice Léon-Bollée, minha marca preferida. Se isso lhe diverte, podemos dar uma volta nele. Não se esqueça de me apresentar à senhora sua mãe (DURAS, 2003, p. 42).

SUZANNE

De que marca é?

M. JO

É um Morris Léon-Bollée (DURAS, 1977, p. 45, tradução nossa). ${ }^{13}$

\footnotetext{
${ }^{13}$ No original: "SUZANNE

Quelle marque c'est?

M. JO

Une Morris Léon-Bollée” (DURAS, 1977, p. 45).
} 
A limusine preta, tanto o Morris Léon-Bollée quanto o Lancia, são familiares para o leitor imaginado pela narradora/escritora. Ela se refere a eles como elementos conhecidos do seu destinatário, familiares nesse universo de textos recriados e reinventados. E, ainda que muitos dos leitores de carne e osso que se deparam com $O$ amante não tenham efetivamente lido os outros livros de Duras, que não reconheçam de fato as histórias retomadas e recriadas no romance, ainda assim eles são convidados a perceber a reescritura, a identificar as marcas de uma escrita que une diversos textos em uma mesma trajetória. Quando essas marcas são identificadas, quando os episódios de textos anteriores são reconhecidos na narrativa retrospectiva e confessional de $O$ amante, tais episódios adquirem o mesmo efeito autobiográfico que é produzido neste último.

Assim, quando se pensa, por exemplo, em Barragem contra o Pacífico isoladamente, não é possível, ou, pelo menos, não é evidente enxergar nele uma autoficção. Porém, quando o analisamos no contexto da reescritura, integrando-o, a partir da chave de $O$ amante, ao todo da obra durassiana, torna-se coerente entende-lo como um tex to autoficcional.

É em $O$ amante que se constrói a figura desse eu-escritora que rememora fatos e escritos. E, por meio da reescritura, o pacto ambíguo que aí se estabelece estende-se a textos anteriores e permite que se pense como autoficcional a relação entre as obras.

\section{Considerações finais}

As referências a outros livros, assumidos e recriados por uma narradora/escritora que se aproxima e se distancia da personagem, mantêm a ambiguidade do aspecto autobiográfico ao mesmo tempo em que focalizam o escrever e a figura desse eu-escritora, fundado na reescritura. Esse eu que narra suas lembranças e as organiza a partir do ritmo mnemônico não é somente uma instância narrativa, uma narradora fictícia, mas um sujeito da reescritura que se deixa construir por essa mesma reescritura. No passado rememorado em $O$ amante, não estão apenas

acontecimentos, mas textos. A memória não é apenas intratextual, mas também intertextual. É memória do dizer, do escrever. Memória dessa escritora de um conjunto de textos que se recriam e se referem uns aos outros incessantemente.

\section{Referências}

ARMEL, Aliette. Marguerite Duras et l'autobiographie. Paris: Le Castor Astral, 1996. 
AYER, Maurício. Marguerite Duras: o cinema como ato político. In: AYER, Maurício; KUNTZ, Maria Cristina Viana (orgs.). Olhares sobre Marguerite Duras. São Paulo: Publisher Brasil, 2014, p. 7-15.

DOUBROVSKY, Serge. Fils. Paris: Galilée, 1977.

DOUBROVSKY, Serge. O último eu. In: NORONHA, Jovita Maria Gerheim (org.). Ensaios sobre a autoficção. Trad. Jovita Maria Gerheim Noronha e Maria Inês Coimbra Guedes. Belo Horizonte: Ed. UFMG, 2014, p. 111-125.

DURAS, Marguerite. Un barrage contre le Pacifique. Paris: Gallimard, 1950.

DURAS, Marguerite. Barragem contra o Pacífico. Trad. Eloisa Araújo Ribeiro. São Paulo: Arx, 2003.

DURAS, Marguerite. L’Éden cinéma. Paris: Mercure de France, 1977.

DURAS, Marguerite. L’amant. Paris: Éditions de Minuit, 1984.

DURAS, Marguerite. L'amant de la Chine du Nord. Paris: Gallimard, 1991.

DURAS, Marguerite. Écrire. Paris: Gallimard, 1993.

DURAS, Marguerite. C’est tout. Paris: Gallimard, 1995.

DURAS, Marguerite. O amante. Trad. Denise Bottmann. São Paulo: Cosac Naify, 2012.

FAEDRICH, Anna. O conceito de autoficção: demarcações a partir da literatura brasileira. Itinerários, Araraquara, n. 40, p. 45-60, jan./jun. 2015.

GASPARINI, Philippe. Autoficção é o nome de quê? In: NORONHA, Jovita Maria Gerheim (org.). Ensaios sobre a autoficção. Trad. Jovita Maria Gerheim Noronha e Maria Inês Coimbra Guedes. Belo Horizonte: Ed. UFMG, 2014, p. 181-221.

LEJEUNE, Philippe. Le pacte autobiographique. Paris: Seuil, 1975.

PERRONE-MOISÉS, Leyla. «O amante » foi o livro de maior sucesso. Folha de São Paulo, São Paulo, 4 mar. 1996, Ilustrada, p. 4.

PINTHON, Monique. Marguerite Duras et l'autobiographie : le pacte de vérité en question. Relief, Nimegue, v. 1, n. 3, p. 30-42, 2009.

Recebido em: 08/07/2019 Aceito para publicação em: 25/11/2019 